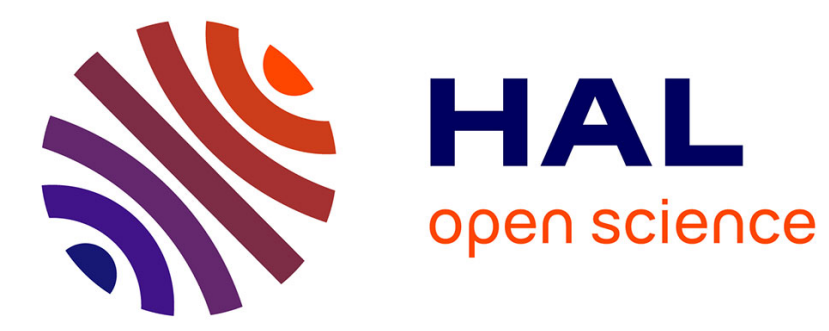

\title{
The Design of Novel 17 $\beta$-Hydroxysteroid Dehydrogenase Type 3 Inhibitors
}

\author{
Nigel Vicker, Christopher M. Sharland, Wesley B. Heaton, Ana M. Ramos \\ Gonzalez, Helen V. Bailey, Andrew M. Smith, Jeremy S. Springall, Joanna M.
}

Day, Helena J. Tutill, Michael J. Reed, et al.

\section{To cite this version:}

Nigel Vicker, Christopher M. Sharland, Wesley B. Heaton, Ana M. Ramos Gonzalez, Helen V. Bailey, et al.. The Design of Novel $17 \beta$-Hydroxysteroid Dehydrogenase Type 3 Inhibitors. Molecular and Cellular Endocrinology, 2009, 301 (1-2), pp.259. 10.1016/j.mce.2008.08.005 . hal-00532062

\section{HAL Id: hal-00532062 https://hal.science/hal-00532062}

Submitted on 4 Nov 2010

HAL is a multi-disciplinary open access archive for the deposit and dissemination of scientific research documents, whether they are published or not. The documents may come from teaching and research institutions in France or abroad, or from public or private research centers.
L'archive ouverte pluridisciplinaire HAL, est destinée au dépôt et à la diffusion de documents scientifiques de niveau recherche, publiés ou non, émanant des établissements d'enseignement et de recherche français ou étrangers, des laboratoires publics ou privés. 


\section{Accepted Manuscript}

Title: The Design of Novel $17 \beta-H y d r o x y s t e r o i d$ Dehydrogenase Type 3 Inhibitors

Authors: Nigel Vicker, Christopher M. Sharland, Wesley B. Heaton, Ana M. Ramos Gonzalez, Helen V. Bailey, Andrew Smith, Jeremy S. Springall, Joanna M. Day, Helena J. Tutill,

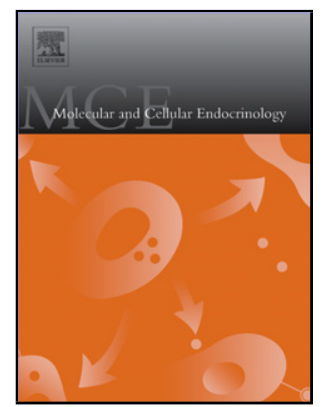
Michael J. Reed, Atul Purohit, Barry V.L. Potter

PII: S0303-7207(08)00354-7

DOI: doi:10.1016/j.mce.2008.08.005

Reference: $\quad$ MCE 6940

To appear in: $\quad$ Molecular and Cellular Endocrinology

Received date: $\quad 30-6-2008$

Revised date: $\quad 4-8-2008$

Accepted date: $\quad$ 6-8-2008

Please cite this article as: Vicker, N., Sharland, C.M., Heaton, W.B., Gonzalez, A.M.R., Bailey, H.V., Smith, A., Springall, J.S., Day, J.M., Tutill, H.J., Reed, M.J., Purohit, A., Potter, B.V.L., The Design of Novel 17 $\beta$-Hydroxysteroid Dehydrogenase Type 3 Inhibitors, Molecular and Cellular Endocrinology (2007), doi:10.1016/j.mce.2008.08.005

This is a PDF file of an unedited manuscript that has been accepted for publication. As a service to our customers we are providing this early version of the manuscript. The manuscript will undergo copyediting, typesetting, and review of the resulting proof before it is published in its final form. Please note that during the production process errors may be discovered which could affect the content, and all legal disclaimers that apply to the journal pertain. 


\title{
The Design of Novel 17ß-Hydroxysteroid Dehydrogenase Type 3 Inhibitors
}

\author{
Nigel Vicker ${ }^{\text {a }}$, Christopher M. Sharland ${ }^{\mathrm{a}}$, Wesley B. Heaton ${ }^{\mathrm{a}}$, Ana M. Ramos Gonzalez ${ }^{\mathrm{a}}$, Helen \\ V. Bailey ${ }^{\mathrm{a}}$, Andrew Smith ${ }^{\mathrm{a}}$, Jeremy S. Springall ${ }^{\mathrm{a}}$, Joanna M. Day ${ }^{\mathrm{b}}$, Helena J. Tutill ${ }^{\mathrm{b}}$, Michael J. \\ Reed $^{\mathrm{b}}$, Atul Purohit ${ }^{\mathrm{b}}$, Barry V. L. Potter. ${ }^{\mathrm{a},}$ * \\ ${ }^{a}$ Medicinal Chemistry, Department of Pharmacy and Pharmacology and Sterix Ltd., University of Bath, \\ Bath, BA2 7AY, UK. \\ ${ }^{b}$ Oncology Drug Discovery \& Women's Health Group, Dept. of Endocrinology \& Metabolic Medicine, \& Sterix \\ Ltd., Imperial College London, London W2 1NY, UK.
}

\footnotetext{
* Corresponding author. Tel.: +44 1225 386639; fax: +44 1225386114.

E-mail address: B.V.L.Potter@Bath.ac.uk
} 


\begin{abstract}
17ß-hydroxysteroid dehydrogenase type $3(17 \beta$-HSD3) is expressed at high levels in the testes and seminal vesicles but has also been shown to be present in prostate tissue, suggesting its potential involvement in both gonadal and non-gonadal testosterone biosynthesis. The role of 17ß-HSD3 in testosterone biosynthesis makes this enzyme an attractive molecular target for inhibition by small molecule inhibitors for the treatment of prostate cancer.

Here we report the design of selective inhibitors of $17 \beta$-HSD3 as potential anti-cancer agents. Due to $17 \beta$-HSD3 being a membrane-bound protein a crystal structure is not yet available. A homology model of 17ß-HSD3 has been built to aid structure-based drug design. This model has been used with docking studies to identify a series of lead compounds that may give an insight as to how inhibitors interact with the active site. Compound $\mathbf{1}$ was identified as a potent selective inhibitor of $17 \beta-\mathrm{HSD} 3$ with an $\mathrm{IC}_{50}=700 \mathrm{nM}$ resulting in the discovery of a novel lead series for further optimization. Using our homology model as a tool for inhibitor design compound 5 was discovered as a novel potent and selective inhibitor of $17 \beta-\mathrm{HSD} 3$ with an $\mathrm{IC}_{50} \sim 200 \mathrm{nM}$.
\end{abstract}

Keywords: Hydroxysteroid dehydrogenase; 17ß-HSD3; Prostate; Cancer

\title{
1. Introduction
}

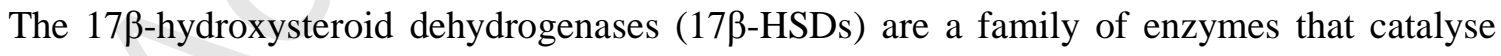
the oxido-reduction of $17 \beta$-alcohol or 17 -keto groups on steroids using $\mathrm{NAD}(\mathrm{P}) \mathrm{H}$ or $\mathrm{NAD}(\mathrm{P})$ as cofactor (Poirier, 2003). These enzymes catalyse the final step in male and female sex hormone biosynthesis. In humans 15 17ß-HSD isozymes have been characterised, 17 $\beta$-HSD types 1-4 and 6-15 belong to the short-chain dehydrogenase/reductase (SDR) family (Lukacik et al., 2006; Moeller \& Adamski, 2006; Luu-The et al., 2008). The 17ß-HSD5 isozyme, however, belongs to the aldo-keto reductase (AKR) family (Penning et al., 2000). 
Prostate cancer is the second most common cancer in males in western countries. As 679,000 new cases are diagnosed each year it represents a therapeutic area with a great unmet medical need. The androgens testosterone (T) and dihydrotestosterone (DHT) are hormones that play an important role in the development of prostate cancer, benign hyperplasia, acne, baldness and hirsutism. Regulation of androgen biosynthesis or its action on the androgen receptor (AR) is central to the management of prostate cancer (van Bokhoven et al., 2003). 17ß-HSD3 is expressed at high levels in the testes and seminal vesicles but has also been shown to be present in prostate tissue, suggesting its potential involvement in both gonadal and non-gonadal testosterone biosyntheses. The role of $17 \beta-$ HSD3 in testosterone biosynthesis makes this enzyme an attractive molecular target for small molecule inhibitors for the treatment of prostate cancer.

$17 \beta$-HSD3 catalyses the formation of testosterone from androstenedione (Laplante \& Poirier, 2008). 17 $\beta$-HSD2 catalyses the reverse reaction and oxidises testosterone to the weaker androgen androstenedione. It has been indicated that expression of 17 $\beta$-HSD3 mRNA increases over 30fold in cancerous prostate biopsies (Koh et al., 2002). Inhibition of 17ß-HSD3 should therefore reduce prostate tumour growth. $17 \beta$-HSD3 inhibitors may also have potential as male antifertility agents.

The $17 \beta-H S D 3$ isozyme uses NADPH as a co-factor in the reductive direction. The cDNA encodes a microsomal protein of 310 amino acids with an apparent molecular mass of $\sim 35 \mathrm{kDa}$ (Moghrabi \& Andersson, 1998). 17 $\beta$-HSD3 is a microsomal enzyme which is bound through the $N$-terminal transmembrane domain to the endoplasmic reticulum (Lukacik et al., 2006).

Recently some potent selective inhibitors have been reported by Schering-Plough and BristolMyers Squibb (BMS) (Fig.1) (Guzi et al., 2004; Fink et al., 2006). Efficacy studies, using SCH451659 , in cynomologus monkeys showed promising results, leading to a $50 \%$ reduction in serum testosterone levels, an $85 \%$ decrease in testicular testosterone levels and a $20 \%$ decrease in prostate weight after 4 weeks dosing at $15 \mathrm{mg} / \mathrm{kg}$, BID, p.o. (Pachter et al., 2005). These results 
illustrate proof of concept in higher mammals, showing that inhibition of $17 \beta-$ HSD3 is a valid target for the treatment of prostate cancer.

\section{Insert Figure 1}

The design of inhibitors of $17 \beta-H S D 3$ as anti-cancer agents is an active area of our research (Vicker et al., 2007). Due to $17 \beta$-HSD3 being a membrane-bound protein a crystal structure is not available. Crystallisation is difficult as the protein has to be removed from the membrane prior to crystallisation, which can alter the tertiary structure. Stabilisation of the protein tertiary structure by adding detergents is a method sometimes used to crystallise such proteins, but to date this has not been successful for $17 \beta$-HSD3. The sequence of $17 \beta$-HSD3 is known; therefore it is possible to build a homology model using a protein from the SDR super-family with high sequence identity. Homology models will obviously not give as accurate a depiction of the active site as a protein crystal structure, but a model can give a broad idea as to how inhibitor compounds, when docked, may fit in the active site. A homology model of 17ß-HSD3 has thus been built to aid structure-based drug design and competitor inhibitors from Schering-Plough and BMS have been docked into it. This model has been used to identify a series of lead compounds, for which docking studies give an insight as to how these novel compounds may interact with the active site. Compound 1 was identified as a potent and selective inhibitor of $17 \beta-\mathrm{HSD} 3$ with an $\mathrm{IC}_{50}=$ $700 \mathrm{nM}$, resulting in the discovery of a novel lead series for further optimisation. Using our homology model as a tool for inhibitor design compound $\mathbf{5}$ was identified as a novel potent inhibitor of $17 \beta$-HSD3 with an $\mathrm{IC}_{50} \sim 200 \mathrm{nM}$. Compound 5 shows an encouraging profile in vitro and initial in vivo studies indicate inhibition of androstenedione-stimulated tumour growth in a mouse model being developed in house (Day et al., 2008).

\section{Methods}


Compounds 1-5 were synthesised from substituted anilino-diphenylethers via a reductive amination reaction as shown in Schemes 1 and 2 (Vicker et al., 2007). Compounds 1 and 2 were prepared using some novel in-house methodology by a reductive amination reaction with anilines and ketones using microwave chemistry as indicated below (Bailey et al., 2006). The general method for the synthesis of $\mathbf{1}$ and $\mathbf{2}$ is outlined below.

To a solution of aniline $(1.00 \mathrm{mmol})$ and ketone $(2.00 \mathrm{mmol})$ in dichloroethane $(2.00 \mathrm{~mL})$ in a microwave vial, was added $\mathrm{NaBH}(\mathrm{OAc})_{3}(2.50 \mathrm{mmol})$ and $\mathrm{AcOH}(3.00 \mathrm{mmol})$. The vial was capped and the resulting solution was heated in a CEM Discover ${ }^{\circledR}$ microwave for 10 minutes at $140{ }^{\circ} \mathrm{C}$. The power was set at 300 Watts and the pressure in the vial was variable during the reaction. The reaction was quenched with a saturated aqueous solution of $\mathrm{NaHCO}_{3}(10 \mathrm{~mL})$ and the mixture then extracted with DCM $(3 \times 15 \mathrm{~mL})$. The combined organics were dried $\left(\mathrm{MgSO}_{4}\right)$, filtered and concentrated in vacuo. Purification by flash chromatography (eluting with DCM) gave the desired products $\mathbf{1}$ and $\mathbf{2}$.

\section{Insert Scheme 1}

\section{1-(4-[2-(4-Chloro-phenoxy)-phenylamino]-piperidin-1-yl)-ethanone (1).}

Mp. $129-130{ }^{\circ} \mathrm{C}$, LCMS: $\operatorname{tr}=5.05 \mathrm{~min}(50 \% \mathrm{MeOH}$ in water at $0.5 \mathrm{~mL} / \mathrm{min}), \mathrm{m} / \mathrm{z} \mathrm{M}+\mathrm{H} 345.40$, HPLC: $\operatorname{tr}=2.45 \mathrm{~min}(90 \%$ acetonitrile in water at $1.0 \mathrm{~mL} / \mathrm{min}),>99 \%,{ }^{1} \mathrm{H} \mathrm{NMR}(\mathrm{CDCl} 3,270$ MHz): $\delta 1.23-1.37$ (2H, m, CH2), 2.01-2.14 (5H, m, CH2, CH3), 2.80-2.90 (1H, m, CH2), 3.13$3.23(1 \mathrm{H}, \mathrm{m}, \mathrm{CH} 2), 3.48-3.52(1 \mathrm{H}, \mathrm{m}, \mathrm{CH}), 3.72-3.78(1 \mathrm{H}, \mathrm{m}, \mathrm{CH} 2), 4.00(1 \mathrm{H}, \mathrm{s}, \mathrm{NH}), 4.37-4.42$ (1H, m, CH2), $6.64(1 \mathrm{H}, \mathrm{td}, \mathrm{J}=6.4,1.2 \mathrm{~Hz}, \mathrm{ArH}), 6.74(1 \mathrm{H}, \mathrm{dd}, \mathrm{J}=8.2,1.5 \mathrm{~Hz}, \mathrm{ArH}), 6.80(1 \mathrm{H}$, $\mathrm{dd}, \mathrm{J}=6.4,1.5 \mathrm{~Hz}, \mathrm{ArH}), 6.84-6.88(2 \mathrm{H}, \mathrm{m}, \mathrm{ArH}), 7.03(1 \mathrm{H}, \mathrm{td}, \mathrm{J}=7.4,1.5 \mathrm{~Hz}, \mathrm{ArH}), 7.21-7.27$ $(2 \mathrm{H}, \mathrm{m}, \mathrm{ArH}) .{ }^{13} \mathrm{C} \mathrm{NMR}(\mathrm{CDCl} 3,101 \mathrm{MHz}): \delta 21.4(\mathrm{CH} 3), 31.9,32.7,40.2,45.0(\mathrm{CH} 2), 49.6$ $(\mathrm{CH}), 112.2,117.2,118.6,119.5,125.2(\mathrm{ArCH}), 127.8(\mathrm{ArC}), 251,129.7(\mathrm{ArCH}), 138.7,142.9$, 156.0 (ArC), 168.8 (CO). Elemental analysis: Calcd for $\mathrm{C}_{19} \mathrm{H}_{21} \mathrm{ClN}_{2} \mathrm{O}_{2}$ : C 66.18, H 6.14, N 8.12\%. Found C 66.0, H 6.06, N 7.90\%. 


\section{1-(4-[2-(2, 4-Chloro-phenoxy)-phenylamino]-piperidin-1-yl)-ethanone (2).}

Mp. $144-145{ }^{\circ} \mathrm{C}$, LCMS tr= $5.40 \mathrm{~min}(50 \% \mathrm{MeOH}$ in water at $0.5 \mathrm{~mL} / \mathrm{min}), \mathrm{m} / \mathrm{z} \mathrm{M}+\mathrm{H} 379.41$, HPLC $\operatorname{tr}=2.65 \mathrm{~min}(90 \%$ acetonitrile in water at $1.0 \mathrm{~mL} / \mathrm{min}), 99 \%,{ }^{1} \mathrm{H}$ NMR $(\mathrm{CDCl} 3,270$ MHz): $\delta$ 1.27-1.43 (2H, m, CH2), 2.4-2.11 (5H, m, CH3, CH2), 2.84-2.94 (1H, m, CH2), 3.15$3.25(1 \mathrm{H}, \mathrm{m}, \mathrm{CH} 2), 3.42-3.55(1 \mathrm{H}, \mathrm{m}, \mathrm{CH}), 3.74-3.78(1 \mathrm{H}, \mathrm{m}, \mathrm{CH} 2), 4.06-4.08(1 \mathrm{H}, \mathrm{m}, \mathrm{NH})$, 4.35-4.43 (1H, m, CH2), 6.60-6.66 (1H, m, ArH), 6.72-6.77 (2H, m, ArH), $6.80(1 \mathrm{H}, \mathrm{d}, \mathrm{J}=2.5$ $\mathrm{Hz}, \mathrm{ArH}), 7.01-7.09$ (1H, m, ArH), $7.13(1 \mathrm{H}, \mathrm{dd}, \mathrm{J}=8.9,2.5 \mathrm{~Hz}, \mathrm{ArH}), 7.44(1 \mathrm{H}, \mathrm{d}, \mathrm{J}=2.5 \mathrm{~Hz}$ ArH). ${ }^{13} \mathrm{C} \mathrm{NMR}(\mathrm{CDCl} 3,101 \mathrm{MHz}): \delta 21.4(\mathrm{CH} 3), 31.8,32.6,40.1,44.9(\mathrm{CH} 2), 49.5(\mathrm{CH})$, 112.3, 117.0, 118.6, 119.5, 125.3, 127.9 (ArCH), 128.5 (ArC), 130.3 (ArCH), 138.2, 142.9, 151.4 (ArC), 168.8 (CO). Elemental analysis: Calcd for $\mathrm{C}_{19} \mathrm{H}_{20} \mathrm{Cl}_{2} \mathrm{~N}_{2} \mathrm{O}_{2}$ : C 60.17, H 5.32, N 7.39 \%, Found C 60.2, H 5.57, N 7.22\%.

Seven membered ring ketones are less reactive than six membered ring ketones and also have added flexibility. Transformations that work on six membered rings do not always translate to their seven ring analogues. The microwave chemistry was unsuccessful for the synthesis of the seven membered ring expanded analogues and an alternative method was designed to access this novel series. For the synthesis of $\mathbf{3}$ and $\mathbf{4}$ traditional reductive amination chemistry was employed; however, reaction times were prohibitively long and a different method was used in the synthesis of 5. The methods for the synthesis of 3-5 and their characterisation data are outlined below.

\section{Insert Scheme 2}

\section{1-(4-[2-(4-chlorophenoxy)phenylamino]azepan-1-yl)ethanone (3)}

To a solution of 2-(4-chlorophenoxy)phenylamine (113 mg, $0.51 \mathrm{mmol})$, 1-acetylazepan-4-one (159 mg, $1.02 \mathrm{mmol})$ and acetic acid $(153 \mathrm{mg}, 2.55 \mathrm{mmol})$ in DCE (4 ml), was added sodium triacetoxyborohydride $(270 \mathrm{mg}, 1.28 \mathrm{mmol})$. The reaction mixture was allowed to stir at room 
temperature for 10 days. The reaction was quenched with saturated aqueous sodium sodium bicarbonate $(15 \mathrm{~mL})$ and extracted with ethyl acetate $(2 \times 15 \mathrm{~mL})$. The combined organics were dried $\left(\mathrm{MgSO}_{4}\right)$, filtered and concentrated in vacuo. Purification by flash chromatography using gradient elution with 9:1 hexane:ethyl acetate to ethyl acetate gave $3(67.1 \mathrm{mg}, 37 \%) .{ }^{1} \mathrm{H}$ NMR $\left(270 \mathrm{MHz}, \mathrm{CDCl}_{3}\right): \delta .1 .49-2.27\left(9 \mathrm{H}, \mathrm{m}, 3 \times \mathrm{CH}_{2}, \mathrm{CH}_{3}\right), 3.30-3.72(5 \mathrm{H}, \mathrm{m}, 5 \times \mathrm{CH}), 4.10(1 \mathrm{H}, \mathrm{br}$ s, NH), 6.59-6.67 (2H, m, Ar-H), 6.78-6.89 (3H, m, Ar-H), 7.00-7.08 (1H, m, Ar-H), 7.21-7.24 ppm $(2 \mathrm{H}, \mathrm{m}, \mathrm{Ar}-\mathrm{H})$. LCMS: $\mathrm{M}^{+} \mathrm{H}:$ 359.45; HRMS: $\mathrm{C}_{20} \mathrm{H}_{24} \mathrm{ClN}_{2} \mathrm{O}_{2}$, requires 381.1340, found 381.1344.

The same methodology was applied to the synthesis of 1-(4-[2-(4chlorophenoxy)phenylamino]azepan-1-yl)ethanone (4) to give a light brown oil in $40 \%$ yield. ${ }^{1} \mathrm{H}$ NMR (270 MHz, $\left.\mathrm{CDCl}_{3}\right): \delta .1 .42-2.27\left(9 \mathrm{H}, \mathrm{m}, 3 \times \mathrm{CH}_{2}, \mathrm{CH}_{3}\right), 3.30-3.72(5 \mathrm{H}, \mathrm{m}, 5 \mathrm{x} \mathrm{CH})$, $4.10(1 \mathrm{H}$, br s, NH), 6.57-6.70 (2H, m, Ar-H), 6.72-6.85 (2H, m, Ar-H), 7.00-7.17 (2H, m, Ar-H), 7.43 ppm $(1 \mathrm{H}, \mathrm{t}, J=2.5 \mathrm{~Hz}, \mathrm{Ar}-\mathrm{H})$. LCMS: $\mathrm{M}^{+} \mathrm{H}$ : 393.45; HRMS: $\mathrm{C}_{20} \mathrm{H}_{23} \mathrm{Cl}_{2} \mathrm{~N}_{2} \mathrm{O}_{2}$, requires 393.1131, found 393.1131.

\section{1-Acetyl-5-[2-(4-Chloro-phenoxy)-phenylamino]-2,3,4,5-tetrahydro-benzo[b]azepine (5).}

To a mixture of 1-butyloxycarbonyl-2,3-dihydro-1H-quinolin-4-one (0.050 g, $0.25 \mathrm{mmol})$ and 2(4-chlorophenoxy)-aniline (0.060 g, $0.27 \mathrm{mmol}, 2.2$ eq.) in toluene (5 mL) was added chlorotriisopropoxytitanium(IV) $(0.3 \mathrm{~mL}, 2$ eq. $)$ and the resulting deep orange solution stirred at room temperature overnight. Saturated $\mathrm{NaHCO}_{3}$ solution $(10 \mathrm{~mL})$ was added and the phases separated. The organic layer was separated dried over anhydrous magnesium sulphate then filtered and evaporated. The residue was re-dissolved in THF $(25 \mathrm{~mL})$ and cooled to $0{ }^{\circ} \mathrm{C}$ under nitrogen. A solution of succinic acid $(0.189 \mathrm{~g}, 1.6 \mathrm{mmol})$ in THF $(5 \mathrm{~mL})$ was added followed by $1 \mathrm{M}$ borane tetrahydrofuran complex $(1.6 \mathrm{~mL}, 2$ eq.). The reaction was allowed to warm to room temperature before the addition of saturated $\mathrm{NaHCO}_{3}$ solution $(100 \mathrm{~mL})$. The volatile solvent was 
removed under reduced pressure then ethyl acetate $(100 \mathrm{~mL})$ was added and the layers separated. The organic layer was dried, evaporated and the residue purified by column chromatography (Flashmaster II, $50 \mathrm{~g}$ column) using 0-30\% ethyl acetate/hexanes with gradient elution to give $\mathbf{5}$ (42 mg, 42\%) as a white solid. Mp. 55-58 ${ }^{\circ} \mathrm{C}$, LRMS $\left(\mathrm{EI}^{+}\right) \mathrm{m} / z$ $429.47\left(\mathrm{M}^{+}+\mathrm{Na}, 100 \%\right)$; HRMS (EI) calcd. for $\mathrm{C}_{24} \mathrm{H}_{23} \mathrm{ClN}_{2} \mathrm{O}_{2}\left(\mathrm{M}^{+}+\mathrm{H}\right)$ 407.1521, found 407.1523; HRMS (FAB ${ }^{+}$) calcd for $\mathrm{C}_{24} \mathrm{H}_{23} \mathrm{ClN}_{2} \mathrm{O}_{2}\left(\mathrm{M}^{+}+\mathrm{H}\right) 406.14$ found $406.30 .{ }^{1} \mathrm{H}$ NMR $\left(270 \mathrm{MHz}, \mathrm{CDCl}_{3}\right) \delta 1.56-1.70(2 \mathrm{H}$, Broad $\left.\mathrm{m}, \mathrm{CH}_{2}\right), 2.01-2.18\left(4 \mathrm{H}\right.$, Broad $\mathrm{m}, \mathrm{CH}_{3}$ and $1 \mathrm{H}$ from $\left.\mathrm{CH}_{2}\right), 2.76\left(1 \mathrm{H}, \mathrm{t}, J=7.91 \mathrm{~Hz}, \mathrm{CH}_{2}\right), 4.37-$ $4.85\left(3 \mathrm{H}\right.$, Broad m, $\mathrm{CH}$ and $\left.\mathrm{CH}_{2}\right), 6.16(1 \mathrm{H}, \mathrm{d}, J=7.2 \mathrm{~Hz}, \mathrm{NH}), 6.55-6.65(1 \mathrm{H}$, Broad $\mathrm{m}, \mathrm{CH})$, 6.77-6.89 (2H, Broad m, 2CH), 6.94-7.00 (2H, Broad m, 2CH), 7.73-7.94 (7H, Broad m, 7CH). ${ }^{13} \mathrm{C}$ NMR $\left(270 \mathrm{MHz}, \mathrm{CDCl}_{3}\right) \delta 23.01\left(\mathrm{CH}_{3}\right), 25.87,34.28,45.93\left(\mathrm{CH}_{2}\right), 54.43(\mathrm{CH}), 122.35$, 117.33, 118.64, 118.85, 119.28, 125.23, 125.96, $128.02(\mathrm{CH}), 128.10(\mathrm{C}), 128.56,129.86(\mathrm{CH})$, $138.89,139.72,139.96,142.69,156.02,169.71$ (C). Elemental analysis: Calcd for $\mathrm{C}_{24} \mathrm{H}_{23} \mathrm{ClN}_{2} \mathrm{O}_{2}$; C 70.84, H 5.70, N 6.88\% Found C 70.83, H 5.68, N 5.71\%.

The inhibition of 17 $\beta$-HSD3 by compounds $\mathbf{1 - 5}$ was measured in vitro using a 293-EBNA-based cell line with stable expression of transfected human 17ß-HSD3, 293-EBNA[HSD3], (Vicker et al., 2007; Day et al., 2008a). The results are shown in Table 1. The selectivity of compounds $\mathbf{1 - 5}$ over 17 $\beta$-HSD1 and 17ß-HSD2 was measured using established methods (Day et al., 2006) and compounds 1-5 were inactive on these isozymes. The observed selectivity is not unexpected as there is relatively low sequence identity between the $17 \beta$-HSDs and their active site residues vary considerably.

Insert Table 1

\section{Homology Model Construction and Molecular Modelling}


A phylogenetic tree (Breitling et.al., 2001) was used as an evolutionary guide to the most closely related proteins to $17 \beta$-HSD3 to identify potentially useful protein templates from which to build a homology model. It was observed that the 17ß-HSD family is split into two distinct branches; the first branch contains types 1, 2, 6, 7 and 9; and the second branch contains types 3, 4, 8 and 10 and so this is the branch of interest.

The crystal structure of $7 \alpha$-hydroxysteroid dehydrogenase (Tanaka et al., 1996), PDB code 1FMC (Berman et al., 2000), was selected as the template from which to build the homology model, as sequence alignment indicated this SDR had the highest sequence identity with $17 \beta$ HSD3 and was in the same branch of the phylogenetic tree as 17 $\beta$-HSD3. This was confirmed by a BLAST analysis (Altschul et al., 1997) comparing the sequence of 17ß-HSD3 with 1FMC and 1FDT (17ß-HSD1) with scores of 51.2 and 43.5 respectively. From the binary complex the monomeric A unit from the protein was used in construction of the model. The sequence alignment was generated using ClustalX (Thompson et al., 1997) gap only columns having been removed. From this alignment the WhatIf homology modelling package (Vriend, 1990) was used to produce the initial model.

The homology model was refined initially using YASARA (Krieger et al., 2002) using the following methodology. Hydrogen atoms were added using the add hydrogen command and terminal groups were modified so that they could be recognised by the YASARA program. The system was optimised in several stages. In the first stage, the system was minimised with the atoms of the backbone atoms constrained. Minimisation was performed using iteratively the NOVA and AMBER force fields as implemented in YASARA. This minimisation step was necessary to remove any steric clashes which may have existed between the side chain atoms and the backbone whilst still protecting the secondary and tertiary structures from damage by misplaced or clashing side chain groups. After three cycles of this process the backbone loop regions were freed and a further three minimisations were performed. This allowed the loop 
regions to adapt to any strain caused by the insertion or deletion of residues without disruption to the secondary and tertiary structure. The SYBYL 7.1 program was used to add the cofactor and a rapid minimisation was performed with fixed backbone atoms to allow the protein to adapt to the presence of the cofactor. A final minimisation was performed using the AMBER FF99 force field as implemented in SYBYL 7.1. No constraints were imposed on any of the atoms during this minimisation as this programme is more tolerant of highly strained and sterically clashing situations and is therefore gentler in the treatment of such systems. Once the system was relaxed out of its initial high energy environment SYBYL 7.1 could be employed to perform minimisations. After each minimisation calculation a PROCHECK (Laskowski et al., 1993) calculation was performed to assess the quality of the model and to ensure that it was improving; the Ramachandran plot obtained after the last minimisation stage is shown in Fig. 2.

The minimised protein structure was then subjected to simulated annealing calculations within SYBYL 7.1, the system was subjected to 15 cycles of simulated anneals with heating to $500^{\circ} \mathrm{K}$ for $1000 \mathrm{fs}$, followed by cooling to $100^{\circ} \mathrm{K}$ for $1500 \mathrm{fs}$. This process was performed to move the protein out of any high energy local minima to lower energy states. This process generated a series of structures from which the single homology model was developed. These structures were then examined and five representative structures were chosen based on the calculated energy of the structure and the Ramachandran plots. These five structures were minimised using SYBYL 7.1 and the AMBER FF99 force field. These optimised structures were used to dock several compounds from a Schering-Plough patent (Guzi et al., 2004). The docking was performed using version 2 of the GOLD package (Jones et al., 1997). Each ligand was docked into the active site of our structures a total of 30 times. The final structure was selected by visual examination of the inhibitor-ligand complexes obtained from this procedure. These inhibitors are known to be potent against $17 \beta$-HSD Type 3 . For this to be the case the compounds must firstly be able to fit into the active site as well as to bind strongly to it. These were the guidelines used to choose a single 
protein model which was subjected to a further series of simulated annealing calculations, this time with SCH-451659 in the active site. The system underwent 15 cycles of simulated anneals with heating to $500^{\circ} \mathrm{K}$ for $1000 \mathrm{fs}$, followed by cooling to $100^{\circ} \mathrm{K}$ for $1500 \mathrm{fs}$. These calculations were performed in SYBYL 7.1 using the AMBER FF99 force field.

The results of the simulated annealing were inspected with reference to both the quality of the protein structure and the conformation of the cofactor and ligand. A single structure was then selected and minimised once again using SYBYL 7.1 and the AMBER FF99 force field. The Ramachandran plot, which gives an indication of the quality of the model, for the final minimised system is depicted in Fig. 2. The coordinates of the model are available on request from the corresponding author.

\section{Insert Figure 2}

It was observed that there is potentially a strong pi-stacking interaction between Phe 205 and one of the aromatic rings of SCH-451659 (not shown). Also, with some movement there could additionally be a further pi-stacking interaction between the second aromatic ring and Tyr212. Also, from the docking a hydrophobic interaction with Val213 and an aromatic ring is observed. The $t$-butyl group occupies a lipophilic pocket formed by Ile148, Phe151, Trp153 and Leu252 which could explain the improved activities observed when lipophilic groups of increasing size are placed in this region.

As a final test of the model for use as an aid in hit identification a 17ß-HSD3 inhibitor from BMS

(Fig1. 1.) was also docked into this homology model to ensure that the active site was not overly optimised for the Schering-Plough type compound and would accept non-related inhibitors. The docking was again performed using the GOLD docking package. The ligand was docked into the active site a total of 30 times.

The homology model below (Fig. 3.) indicates that the substrate binding site in the protein is highly hydrophobic in nature. Key hydrophobic residues are indicated in grey. The aromatic rings 
on the diphenyl ether group in our inhibitors may potentially form pi-pi interactions with Phe205 as well as other hydrophobic interactions with residues such as Val213 and Leu252. The homology model was then used as a tool in structure-based drug design by docking potential target molecules to discover novel 17 $\beta$-HSD3 inhibitors

\section{Insert Figure 3}

Compound 3 (left above in grey) is depicted docked into the active site of the homology model with some key hydrophobic residues highlighted (magenta). In a similar fashion compound $\mathbf{5}$ (right above in grey) is also shown in which a hydrophobic region is occupied by the fused benzo ring. The acetyl group in compounds $\mathbf{3}$ and $\mathbf{5}$ is in the region of the nicotinamide group of the cofactor (green) where hydrogen bond interactions are likely. The aromatic ring of the benzazepine in compound 5 may have additional $\pi$-stacking effects with Trp153, Phe151 and Tyr159.

\section{Results and Discussion}

The development of $17 \beta$-HSD3 inhibitors is at a relatively early stage and no clinical candidates have been reported. Both Schering-Plough and BMS have reported potent selective non-steroidal inhibitors as promising leads (Guzi et al., 2004; Fink et al., 2006). Based on highly preferred structures from the Schering-Plough patents a pharmacophore was constructed and used in virtual screening of the Maybridge database to discover potential lead templates for further modification. The pharmacophore consisted of hydrophobic aromatic groups based on the diphenylmethylene moiety, a hydrophobic group based on the $t$-butyl substituent and a distal hydrogen bond acceptor representing the $\mathrm{N}$-acetyl moiety. This resulted in the identification of a potential hit with a diphenylether 'hydrophobic head' that could mimic the diphenylmethylene moiety in SCH-451659 and related structures (Scheme 3). Key features of SCH-451659 are 
thought to be the aromatic hydrophobic head, a functionalised spacer or linking group and a hydrogen bond acceptor distal from the hydrophobic head.

\section{Insert Scheme 3}

From the structure of SCH-451659 and our database hit, compound 1 (Scheme 1) was proposed as an initial target. It was very encouraging that compound $\mathbf{1}$ showed a good inhibition of $17 \beta$ HSD3 with an $\mathrm{IC}_{50}=770 \mathrm{nM}$ and was selective over both $17 \beta-\mathrm{HSD} 1$ and $17 \beta-\mathrm{HSD} 2$ making it a and novel promising new lead. Further substitution in one of the aromatic rings of the diphenylether with a chlorine gave 2 which resulted in a $\sim 3$ fold loss of activity with an $\mathrm{IC}_{50}=$ $2.4 \mu \mathrm{M}$. However the loss was not dramatic and indicates that further substitutions in the hydrophobic head are tolerated. When compound $\mathbf{1}$ was docked into our homology model (not shown) it was clear that there was additional space available in the active site which could be exploited to achieve further inhibitor interactions the region of the piperidine moiety. As the active site is very hydrophobic in nature (Fig. 3) an initial proposed change was to ring expand compound 1 to give compound 3. This change would give a more flexible 7 -membered ring system and add some more hydrophobicity to the molecule. Compound $\mathbf{3}$ had an $\mathrm{IC}_{50}=1.8 \mu \mathrm{M}$ and is $\sim 2$ fold less potent than $\mathbf{1}$ and thus shows similar potency. Importantly, the ring expansion from piperidine to azepine is tolerated and gives rise to another novel series of $17 \beta-\mathrm{HSD} 3$ inhibitors for further optimisation. Substitution in one of the aromatic rings of the diphenylether with a chlorine to give 4 resulted in a compound with $\sim 2$ fold more activity than 3 with an $\mathrm{IC}_{50}=$ $900 \mathrm{nM}$. This again showed that substitution in the hydrophobic head is tolerated and this may be a way to design compounds with different physicochemical properties. When compound $\mathbf{3}$ was docked into our homology model (Fig. 4) it was apparent that there was scope for substitution on the azepine ring to potentially give rise to further interactions with lipophilic residues in the active site. Docking studies (Fig. 4) indicated that fusion of a benzene ring to the azepine may be capable of filling space in the active site region to achieve such interactions in a similar fashion to 
the $t$-butyl group in $\mathrm{SCH}-451659$. Indeed, compound 5 proved to be a potent selective inhibitor of $17 \beta-\mathrm{HSD} 3$ with an $\mathrm{IC}_{50} \sim 200 \mathrm{nM}$ in our whole cell assay, giving a 9 fold improvement over compound 3. This result is very encouraging as docking to the homology model had given an insight as to the structural modifications required to improve a ligand's potency and hence showed the usefulness of the model as an aid to structure based drug design.

\section{Conclusions}

We have built and tested a 17ß-HSD3 homology model that can, at least partially, explain the trends in activity displayed for both Schering-Plough and BMS compounds as 17 $\beta$-HSD3 inhibitors. A new series of novel potent and selective inhibitors of human 17 $\beta$-HSD3 has been discovered by the application of structure based drug design encompassing pharmacophore generation, database mining, homology model construction and docking. Compound $\mathbf{5}$ shows an encouraging profile in vitro and initial in vivo studies indicate inhibition of androstenedionestimulated tumour growth in a mouse model (Day et al., 2008). Further lead optimisation is currently ongoing in this promising series.

\section{Acknowledgements}

This research was supported by Sterix Ltd., a member of the Ipsen group. We thank Ms. A. C. Smith for expert technical assistance and Dr. M. Szeto for performing the BLAST analysis.

\section{References}

Altschul, S.F., Madden, T.L., Schäffer, A.A., Zhang, J., Zhang, Z., Miller, W., Lipman, D.J., 1997. Gapped BLAST and PSI-BLAST: a new generation of protein database search programs. Nucleic Acids Res. 25, 3389-3402. 
Bailey, H.V., Heaton, W., Vicker, N., Potter, B.V.L., 2006. Rapid microwave-assisted reductive amination of ketones with anilines Synlett. 2444-2448.

Berman, H. M.; Westbrook, J.; Feng, Z.; Gilliland, G.; Bhat, T.N.; Weissig, H.; Shindyalov, I. N.;

Bourne, P. E., 2000. The Protein Data Bank. Nucleic Acids Research. 28, 235-242.

Breitling, R., Laubner D., Adamski J., 2001. Structure-based phylogenetic analysis of short-chain alcohol dehydrogenases and reclassification of the 17beta-hydroxysteroid dehydrogenase family. Molecular Biology and Evolution. 18, 2154-2161.

Day, J.M., Tutill, H.J., Newman, S.P., Purohit, A., Lawrence, H.R., Vicker, N., Potter, B.V.L., Reed, M.J., 2006. 17ß-Hydroxysteroid dehydrogenase Type 1 and Type 2: Association between mRNA expression and activity in cell lines. Mol. Cell. Endocrinol. 248, 246-249.

Day, J.M., Tutill, H.J., Foster, P.A., Bailey, H.V., Heaton, W.B., Sharland, C.M., Vicker, N., Potter, B.V.L., Purohit, A., Reed, M.J., 2008. Development of hormone-dependent prostate cancer models for the evaluation of inhibitors of $17 \beta$-hydroxysteroid dehydrogenase type 3 . (Submitted, this issue)

Fink, B.E., Gavai, A.V., Tokarski, J.S., Goyal, B., Misra, R., Xiao, H.Y., Kimball, S.D., Han, W.C., Norris, D., Spires, T.E., You, D., Gottardis, M.M., Lorenzi, M.V., Vite, G.D., 2006. Identification of a novel series of tetrahydrodibenzazocines as inhibitors of $17 \beta$ hydroxysteroid dehydrogenase type 3. Bioorg. Med. Chem. Lett. 16, 1532-1536.

Guzi, T. J., Liu, Y., Doll, R. J., Saksena, A., Girijavallabhan, V. M., Pachter, J.A., 2004. 17ßHydroxysteroid dehydrogenase type 3; Inhibitors for the treatment of androgen dependent diseases. WO 046111 A1.

Jones, G., Willett, P., Glen, R.C., Leach, A.R., Taylor, R., 1997. Development and validation of a genetic algorithm for flexible docking. J. Mol. Biol., 267, 727-748.

Koh, E., Noda, T., Kanaya, J., Namiki, M., 2002. Differential expression of 17ß-hydroxysteroid dehydrogenase isozyme genes in prostate cancer and noncancer tissues. Prostate 53, 154-159. 
Krieger, E., Koraimann, G., Vriend, G., 2002. Increasing the precision of comparative models with yasara NOVA-a self-parameterizing force field. Proteins: Structure, Function, and Genetics 47, 393-402.

Laplante, Y., Poirier, D., 2008. Proliferative effect of androst-4-ene-3,17-dione and its metabolites in the androgen-sensitive LNCaP cell line. Steroids 73, 266-271.

Laskowski, R.A., MacArthur, M.W., Moss, D.S., Thornton, J.M,. 1993. PROCHECK: a program to check the stereochemical quality of protein structures. J. Appl. Cryst., 26, 283-291.

Lukacik, P., Kavanagh, K.L., Oppermann, U., 2006. Structure and function of human 17ßhydroxysteroid dehydrogenases. Mol. Cell. Endocrinol. 248, 61-71.

Luu-The, V., Belanger, A., Labrie, F., 2008. Androgen biosynthetic pathways in the human prostate. Best Practice \& Research Clinical Endocrinology \& Metabolism 22, 207-221.

Moeller, G., Adamski, J., 2006. Multifunctionality of human 17ß-hydroxysteroid dehydrogenases. Mol. Cell. Endocrinol. 248, 47-55.

Moghrabi, N., Andersson, S., 1998. 17beta-hydroxysteroid dehydrogenases: physiological roles in health and disease. Trends in endocrinology and metabolism, 9, 265-70.

Pachter, J., Huryk, R., Ramos, R., Meredith, J., Weinbauer, G., Guzi, T., 2005. Inhibition of $17 \beta-\mathrm{HSD}$ as a novel approach to treat androgen dependent prostate cancer: efficacy in cynomolgus monkeys, 96th Annual Meeting of the American Association for Cancer Research, Anaheim, California.

Penning, T.M., Burczynski, M.E., Jez, J.M., Hung, C.F., Lin, H.K., Ma, H., Moore, M., Palackal, N., Ratnam, K., 2000. Human 3a-hydroxysteroid dehydrogenase isoforms (AKR1C1AKR1C4) of the aldo-keto reductase superfamily: functional plasticity and tissue distribution reveals roles in the inactivation and formation of male and female sex hormones. Biochem. J. $351,67-77$. 
Poirier, D., 2003. Inhibitors of 17 $\beta$-hydroxysteroid dehydrogenases. Curr. Med. Chem. 10, 453477.

Tanaka, N., Nonaka, T., Tanabe, T., Yoshimoto, T., Tsuru, D., Mitsui, Y. 1996. Crystal structures of the binary and ternary complexes of 7 alpha-hydroxysteroid dehydrogenase from Escherichia coli. Biochemistry. 35, 7715-7730.

Thompson, J.D., Gibson, T.J., Plewniak, F., Jeanmougin, F. and Higgins, D.G., 1997. The ClustalX windows interface: flexible strategies for multiple sequence alignment aided by quality analysis tools. Nucleic Acids Research, 24, 4876-4882.

van Bokhoven, A., Varella-Garcia, M., Korch, C., Johannes, W.U., Smith, E.E., Miller, H.L. Nordeen, S. K., Miller, G. J., Lucia, M. S., 2003. Molecular characterization of human prostate carcinoma cell lines, Prostate, 57 , 205-225.

Vicker, N., Day, J.M., Bailey, H.V., Heaton, W.B., Gonzalez, A.M.R., Sharland, C.M., Reed, M.J., Purohit, A., Potter, B.V.L., 2007. Preparation of substituted aliphatic amines for use as anticancer or therapeutic agents inhibiting 17ß-hydroxysteroid dehydrogenase. WO 2007003934 A2.

Vriend, G., 1990. WHAT IF: A molecular modeling and drug design program. J. Mol. Graph., 8, 52-56. 

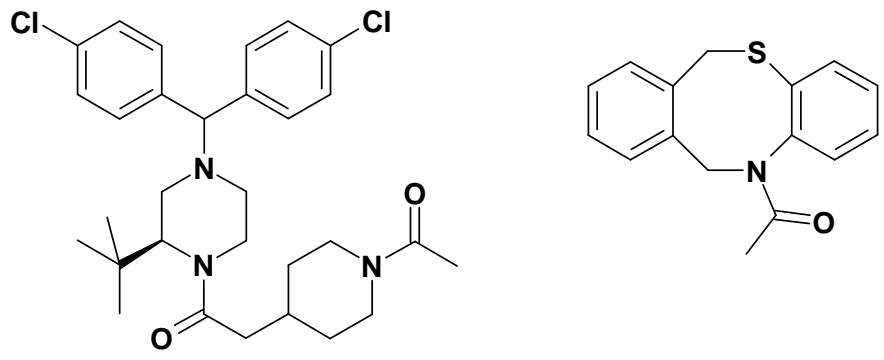

SCH-451659

Fig.1. Structures of Schering-Plough (SCH-451659) and BMS inhibitors of 17ß-HSD3. 

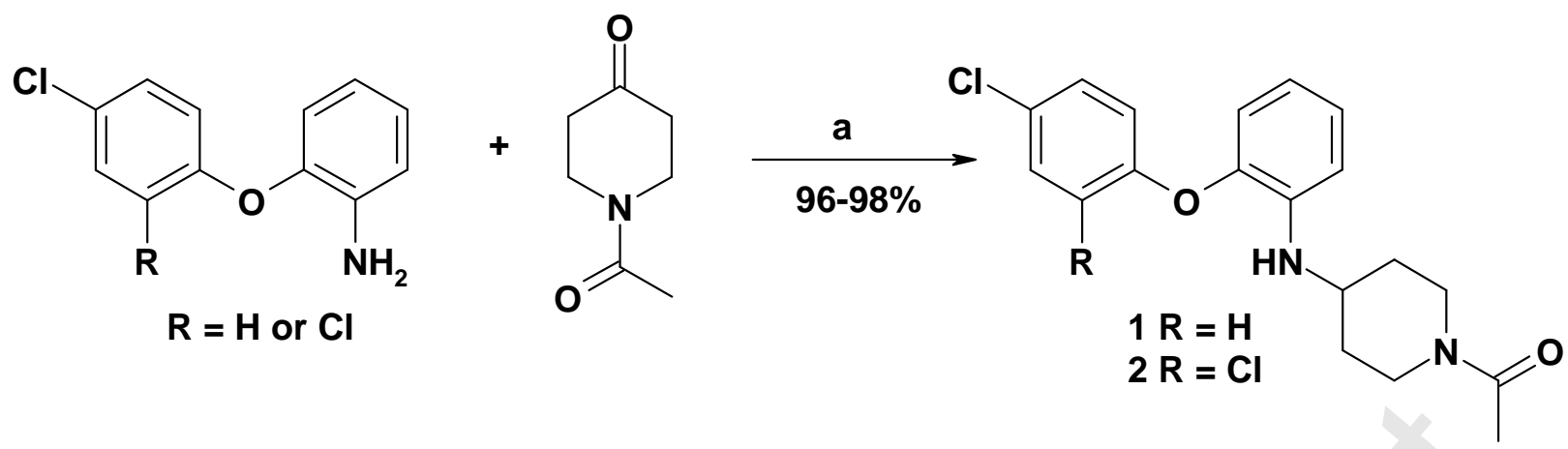

Scheme 1. Synthesis of substituted piperidine compounds $\mathbf{1}$ and 2. Reagents and conditions: (a) $\mathrm{NaBH}(\mathrm{OAc})_{3}, \mathrm{AcOH}$, Dichloroethane, $\mu \mathrm{W} 140^{\circ} \mathrm{C} 300 \mathrm{~W}$ for $10 \mathrm{~min}$. 
<smiles>[R]c1cc(Cl)ccc1Oc1ccccc1N</smiles><smiles>CC(=O)N1CCC(=O)CC1C</smiles><smiles>CC=CC</smiles>

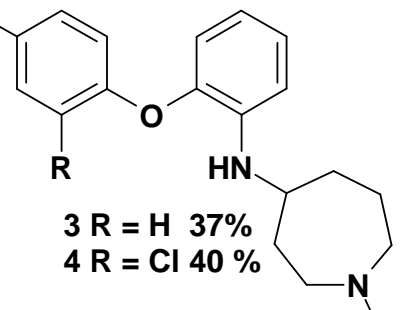<smiles>Nc1ccccc1Oc1ccc(Cl)cc1</smiles><smiles>CC(=O)N1CCCC(=O)c2ccccc21</smiles>
5

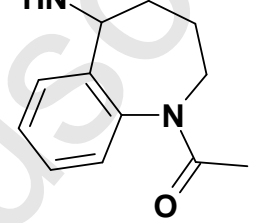

Scheme 2. Synthesis of substituted azepine compounds 3-5. Reagents and conditions:

$\mathrm{NaBH}(\mathrm{OAc})_{3}, \mathrm{AcOH}$, Dichloroethane, room temperature for 10 days. (b) $\mathrm{TiCl}(\mathrm{OiPr})_{3}$, toluene followed by $1 \mathrm{M} \mathrm{BH}_{3}$ in THF. 


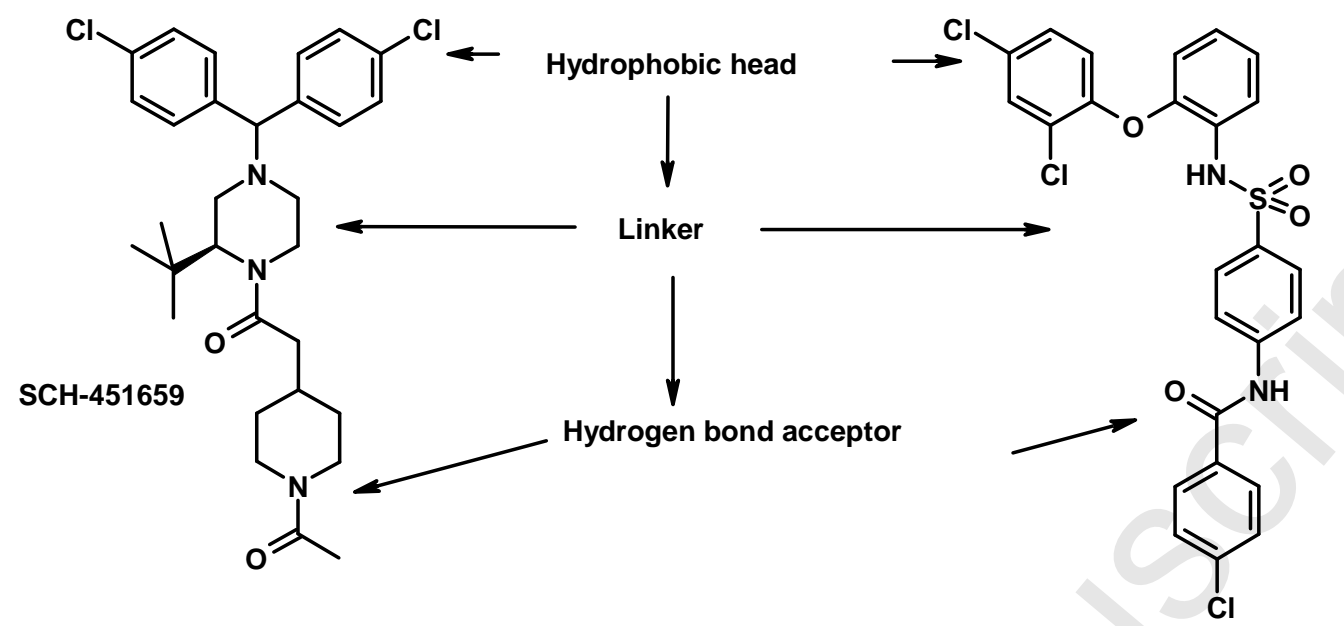

Hit from database mining

Scheme 3. Structure of the hit compound from database mining. 
Table 1. Inhibition of 17ß-HSD3 by compounds $\mathbf{1 - 5}$ in human 293-EBNA[HSD3] cells.

\begin{tabular}{|l|l|l|}
\hline Compound & $\begin{array}{c}\text { IC } 50 \text { 293-EBNA [HSD3] } \\
\text { cells (nM) }\end{array}$ \\
\hline 1 & & \\
\hline 2 &
\end{tabular}




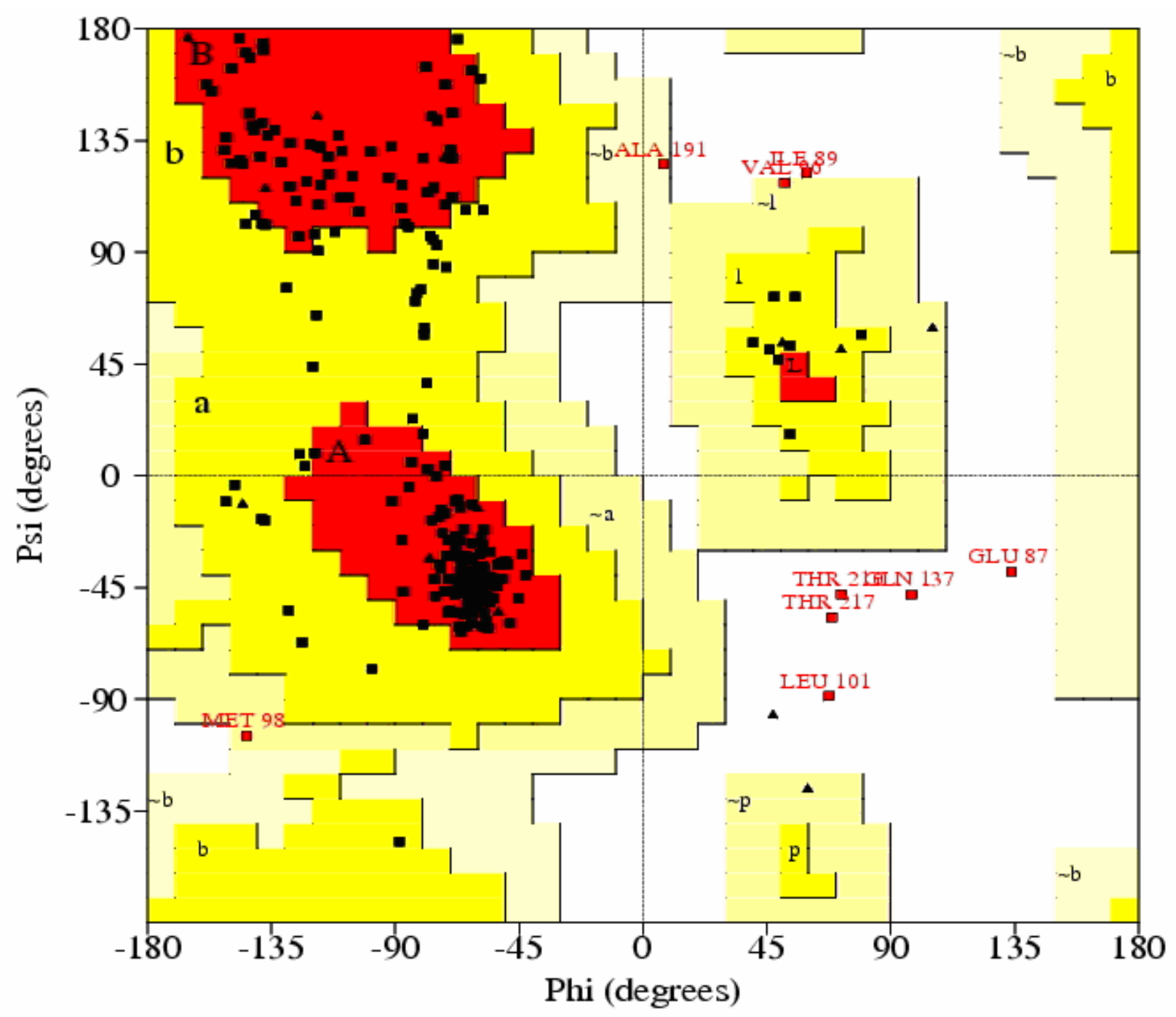

Plot statistics

$\begin{array}{lrr}\text { Residues in most favoured regions [A,B,L] } & 190 & 79.2 \% \\ \text { Residues in additional allowed regions [a,b,l,p] } & 41 & 17.1 \% \\ \text { Residues in generou sly allowed regions [ a, } \sim \mathrm{b}, \sim 1, \sim \mathrm{p}] & 3 & 1.2 \% \\ \text { Residues in disallowed regions } & 6 & 2.5 \% \\ \text { Number of non-glycine and non-proline residues } & 240 & 100.0 \% \\ \text { Number of end-residues (excl. Gly and Pro) } & 3 & \\ \text { Number of glycine residues (shown as triangles) } & 17 \\ \text { Number of proline residues } & 8 & \\ \text { Total number of residues } & 268\end{array}$

Figure 2: Ramachandran plot for the final homology system. 


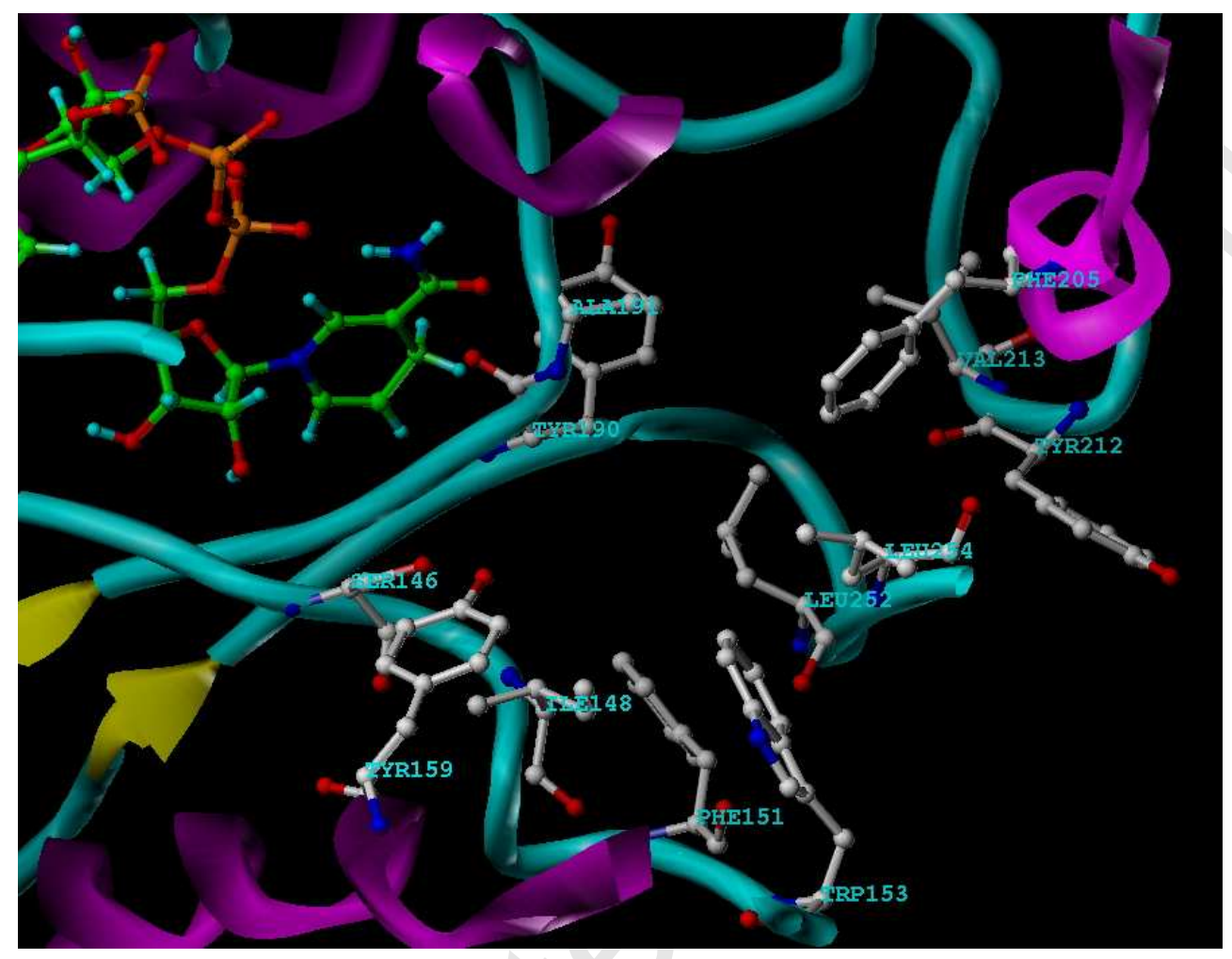

Fig. 3. Active site of $17 \beta$-HSD3 of the homology model with hydrophobic residues in grey and the nicotinamide residue of the cofactor in green. 


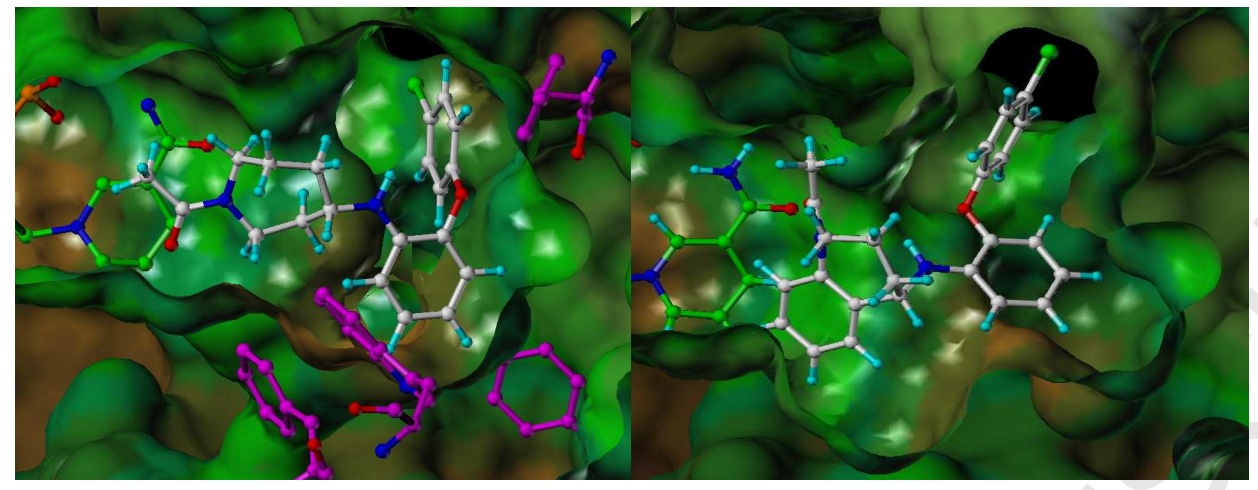

Panel (a)

Panel (b)

Fig. 4. Panel (a) and panel (b) depict compounds $\mathbf{3}$ and $\mathbf{5}$ docked in the active site of the homology model of 17ß-HSD3. 